\title{
A Survey on Preservice English Teachers' Intercultural Communicative Competence in China
}

\author{
Wanrong Lei ${ }^{1}$ \\ ${ }^{1}$ Public Foreign Language Teaching Department, Hunan First Normal University, Changsha, China \\ Correspondence: Wanrong Lei, Public Foreign Language Teaching Department, Hunan First Normal University, \\ Changsha, China.
}

Received: November 6, 2020

Accepted: December 9, 2020

Online Published: December 14, 2020

doi: $10.5539 /$ elt.v14n1p37

URL: https://doi.org/10.5539/elt.v14n1p37

\begin{abstract}
Enhancing pupils' intercultural communication competence (ICC) is a key EFL teaching goal in China and the pre-service English teachers' ICC plays an essential role in it. This study aims to investigate the pre-service English teachers' ICC levels and whether there were any differences between their ICC levels and their genders or their family origins in a public university in China. Data were collected from 186 pre-service English teachers by employing Zhong et al.'s (2013) "Intercultural Communication Competence Self Rating Scale (ICCSRS)". The results showed that the pre-service English teachers' ICC is only moderate with an average score of 3.20. Among the eight dimensions of the ICC, attitude showed the highest score (3.87) while linguistic competence showed the lowest (2.72). In addition, the study revealed the female pre-service English teachers have higher ICC than the male ones, but there is no difference between the urban and rural pre-service English teachers. As a result of the pre-service English teachers' low level of ICC, the study suggested that the university should lay more emphasis on the ICC development in the teaching, provide more opportunities to communicate interculturally for the pre-service English teachers, and take a flexible policy in the class division and teaching.
\end{abstract}

Keywords: assessment inventory, intercultural communicative competence, pre-service English teacher, primary English

\section{Introduction}

With the close relationship between language and culture has been widely acknowledged, intercultural communicative competence (ICC) has become one of the teaching goals in many countries. For example, CEFR (2011) gives considerable importance to the promotion of ICC apart from the focus on the four language skills. The teaching of English as a foreign or second language is not only to enable the students to master a high level of language skills, but also a high level of ICC.

In China, English teaching has received great importance. The English Curriculum Standards (2001) stipulated that "every primary school should provide English course in the third year, and those regions or schools where conditions permit could offer English course in the first year and no less than three English teaching lessons per week should be guaranteed." Under the new situation, the ministry of education brought up new objectives for English teaching, and the ICC has become one of the teaching goals for English teaching both in higher education and basic education. The English Teaching Syllabus for English Major Program in Higher Education (2000) stipulated in the teaching requirements that "focusing on the cultivation of intercultural communicative competence. In the teaching of professional courses, attention should be paid to cultivating students' sensitivity, tolerance and flexibility in dealing with cultural differences" (p. 12). As for the basic education, the English Curriculum Standards (2011) stipulated that the general goal of English teaching is to develop students' comprehensive capability of language use, which includes five dimensions of learning strategy, emotion and attitude, language knowledge, language skills, and cultural awareness.

Due to this increasing recognition of the ICC as a key component of language teaching, much research has been carried out on this topic in China. Some studies have researched the close relationship between intercultural communication competence and ELT practices (e.g., Lin, 1996; Jia, 1997; Hu, 1999; Gao, 2000), and some studies try to construct ICC models or assessment models (e.g., Zhang \& Yang, 2012; Gao, 2014).

To cultivate students' ICC, teachers' ICC levels play a significant role because they help teachers to understand 
and experience how language and culture shape peoples' worldviews, and then influence their teaching practices (Byram, 1986, 1997; Crozet et al., 1999; Crozet, 2017; Liddicoat \& Scarino, 2013). Therefore, some scholars (e.g., Alqefari, 2019) examined the EFL teachers' ICC levels. However, there are few studies which have assessed pre-service English teachers' ICC, especially in the Chinese context. The pre-service English teachers, or the senior undergraduates majoring in English Education, will be assigned to every corner of the country for English teaching. The pre-service teachers' ICC levels will exert great influence on their teaching practices because their ICC levels can affect their attitudes towards the intercultural contents or intercultural activities in the classes. A survey on the pre-service teachers' ICC will help to understand the importance of ICC in English teaching, reveal the problems existing in the ICC training, and provide suggestions for improving the ICC teaching of pre-service English teachers. Therefore, this paper aims to investigate the current ICC of pre-service English teachers at a public normal university in China. It tries to answer the following research questions:

1. What is the current level of the pre-service English teachers' ICC in China?

2. What is the correlations between the pre-service English teachers' ICC and their genders and family origins?

\section{Literature Review}

The term "intercultural communicative competence (ICC)" has been defined by many scholars in recent decades (Byram, 1995, 2002; Sercu, 1995; Chen, 1989; Fantini, Arias-Galicia, \& Guay, 2001; Kim \& Hubbard, 2007) from their own research purposes. After a survey with scholars and university administrators on the components of ICC, Deardorff (2006) pointed out, ICC is "the ability to communicate effectively and appropriately in intercultural situations based on one's intercultural knowledge, skills, and attitudes" (p. 241-242).

Similarly, Chen and Starosta (1996) viewed ICC as "the ability to effectively and appropriately execute communication behavior to elicit a desired response in a specific environment" (p. 352). According to Fantini et al. (2001), ICC involves three abilities: the ability to develop and maintain relationships, the ability to communicate appropriately, and the ability to reach a mutual understanding with others. There are five dimensions in ICC construction, that is, awareness, attitudes, skills, knowledge, and proficiency in using the target language.

In China, Xu (2009) regarded ICC as the ability [in additional language] to communicate effectively and appropriately with people from other language and cultural background.

Although scholars have different descriptions, it can be concluded that ICC mainly involves awareness of different values, attitudes and behaviors of the others, as well as the skills to deal with them.

\subsection{The Models of ICC}

In order to help improve students' ICC development in English teaching, an increasing number of studies are being conducted to develop a model to incorporate ICC in language education programs.

Bennet (1993) proposed the Developmental Model of Intercultural Sensitivity (DMIS) for improving the intercultural communication competence, necessary in the development of cultural sensitivity. The DMIS model implies going through several phases in experimenting the difference and the development of this sensitivity, within a continuum of five phases: denial, defense, minimization, acceptance, adaptation, and integration. However, the DMIS model was abstract and impractical in reality.

Starting from the idea that the intercultural communication process needs the development of interpretation skills, establishing relations between cultures, that is, discovery and interaction, Byram (1997) proposed a model of ICC.

Byram's (1997) model includes five components. The first one is an individual's attitudes (savoir-être), which refers to curiosity and openness, readiness to give up one's disbeliefs about other cultures and beliefs about one's own. The second component of ICC is knowledge (savoir), which includes both specific and general knowledge. The third component is skills of interpreting and relating (savoir-comprendre), which mean the ability to interpret communication and habits in another culture and relate them to those in one's own culture. The fourth component is skills of discovery and interaction (savoir apprendre/faire), which refer to the ability to know how to capitalize on real-time communication by asking people from other cultures about their values, beliefs and behaviors. Finally, a fifth crucial component of ICC is critical cultural awareness (savoir-s' engager), relating to the ability to evaluate, critically and on the basis of explicit criteria, perspectives, practices, processes and products in one's own and other cultures. Byram's model was most influential in constructing ICC components.

Byram's (1997) ICC model greatly broadens the concept of ICC and pays attention to the interactive relationship between various abilities, which helps to comprehensively understand the ICC. However, this model does not explain the reasons for differentiating the two concepts of intercultural competence and intercultural communicative competence, nor their internal connections. In addition, the primary and secondary relationships 
between the five abilities need to be further explored.

To find out the specific components of ICC that need to be delineated for institutions to assess students' ICC, Deardorff (2006) also developed two models of ICC with an attempt to provide guidance for administrators to assess ICC. Deardorff's (2006) pyramid model of ICC consists of three levels: the first level includes the necessary attitudes, the second includes an interactive relationship between knowledge and understanding, and skills: the deeper the understanding of cultural knowledge or information, the faster the improvement of intercultural skills, and vice versa. The third level is the ideal internal result: adaptability, flexibility, national cultural relativity and empathy. The top of the pyramid is the ideal external result, that is, effective and appropriate intercultural communication.

Deardorff's pyramidal model of ICC equates intercultural competence with intercultural communicative competence. It mainly discusses the important relations between knowledge and skills in intercultural communication, which has important methodological implications for the construction of an ICC assessment system.

In China, Wen (1999) believed that ICC consists of communicative competence and intercultural competence. Communicative competence includes linguistic competence, pragmatic competence and strategic competence, and intercultural competence includes sensitivity to cultural differences, tolerance to cultural differences and flexibility in dealing with cultural differences.

Although these models were developed from different research needs and were composed of different structures, they helped researchers to understand ICC in concrete ways. These models shared similarities in requiring language users to have appropriate intercultural attitudes, knowledge, skills and strategies and proposed that effective communication occurs only if the communicators possess the ability to understand and appreciate the differences of others' cultures.

\subsection{The Assessment of ICC}

To help students develop their ICC, an important issue is to assess their ICC levels. Some intercultural specialists have worked on the design of ICC assessment instruments since the 1970s. Ruben (1976) identified seven elements and created a general model for intercultural communication competence. His Intercultural Behavioral Assessment Indices (IBAI) was an instrument to measure ICC. Ruben (1976)) found that Ruben's instrument was mostly reliable; however, he also observed there were disadvantages as well, in that the instrument was too lengthy and imprecise.

Byram (1997) listed detailed ICC teaching, learning and assessment objectives from the four savoir dimensions. It required a long observing period and much effort. Kelley and Meyers (1995) developed a "Cross-Cultural Adaptability Inventory (CCAI)" consisting of 50 items. The evaluation elements include emotional adaptability, flexibility, openness, sensitivity and individual autonomy. Hammer et al. (2003) compiled an "Intercultural Development Inventory (IDI)" with 50 questions to measure people's ICC. These measures were mainly developed for ESL learners or employees in America or Europe.

In China, some scholars have tried to adapt or develop ICC assessment instruments for Chinese students. Gao (2014) developed the "Intercultural Communication Competence Inventory for Chinese College Students" (ICCICCS), which consists of two mutually interactive dimensions of "knowing" and "doing". "Knowing" was further divided into three modular of knowledge, awareness, thinking, and "doing" was divided into attitudes, skills, and strategy. Gao's ICCCCS emphasized the interaction of different aspects, but the complete form is not accessible.

Adapted Byram's (1997) and Wen' (1999) models, Zhong at al. (2013)'s developed an ICC model for Chinese English major undergraduates, which included two dimensions, i.e. communicative competence and intercultural competence. Communicative competence includes linguistic competence, sociolinguistic competence, discourse competence and strategic competence, while intercultural competence consists of four components: skills, knowledge, attitude and consciousness. Based on this model, they developed the "Intercultural Communication Competence Self Rating Scale" (ICCSRS) to assess Chinese learners' ICC, which was composed of a total of 76 items. This instrument, being popular and practical in China (Hua, 2019), was adopted as the instrument in this study. 


\section{Methodology}

\subsection{Instrument}

This study adapted Zhong et al.'s (2013) ICCSS from 76 items into 50 items by deleting overlapped items, adding more items relating to writing and translation, modifying not-easy-to-answer items. It includes eight subdimensions, and in a 5-point scale, with 1 stands for strongly disagree, 2 for disagree, 3 for undecided, 4 for agree and 5 for strongly agree. It consists of two dimensions: communicative competence which was further divided into linguistic competence, sociolinguistic competence, discourse competence and strategic competence, and intercultural competence which was further divided into intercultural knowledge, attitudes, awareness and skills (See Appendix). The Cronbach's Alpha for the instrument was 0.824, which meant the good internal consistency of the questionnaire.

\subsection{Participants}

All the five intact classes of 201 students in Primary English Education major at their first semester of the fourth year were invited to take part in the survey at the researcher's university, which is a normal university in central China, aiming to cultivate teachers for primary education. The participants were admitted from junior middle schools, and they signed the contracts with their home educational bureaus that require them to return to teach in the countryside schools. Among them, 22 participants were male and 179 were female. Their ages ranged from 17 to 19, and they have had the experiences of English learning for 12 years. While the survey of this research was carrying out, most students did not have any teaching experience.

\subsection{Data Collection and Data Analysis}

The questionnaire was delivered through the online survey platform "wenjuanxing" (www.wjx.cn). With the help of a teacher of these five classes, the researcher went into their classroom, explained the research purposes, and informed of the link on which the questionnaire was posted and invited the participants to complete the questionnaire within five days. Finally, 186 complete responses were collected. Five responses were not complete and 10 students did not give any response, so the valid response rate was $92.5 \%$.

After the data collection, the results were inputted the software SPSS21.0 to sort the data and rescore the reversed items. Cronbach's Alpha was used to test the overall reliability of the scale; descriptive statistics were used to list the average levels and standard deviation of eight sub-categories of pre-service English teachers' ICC; and an independent sample t-test was used to analyze the differences between the pre-service English teachers' ICC and their gender as well as family origins.

In this study, the average scores were used to judge the pre-service English teachers' ICC levels in a total and in different dimensions based on the following criteria: an average score below 2.49 is regarded as a low level, between 2.50 and 2.99 is acceptable. If the average score is between 3.00 and 3.49 , the level of the total ICC or the corresponding dimension is moderate. If the average score is above 3.50, the level of the total ICC or the corresponding dimension is high (Sevimel-Sahin, 2020).

\section{Results}

The rating scale for pre-service teachers' ICC consists of eight sub-dimensions, that is, linguistic competence, sociolinguistic competence, discourse competence, strategic competence, skill, knowledge, attitude, and awareness. This next section presents the results from the overall level of ICC and the relationship between the pre-service English teachers' ICC and gender as well as family background.

\subsection{The Level of Pre-Service English Teachers' ICC}

The scale used in this study is to comprehensively measure the ICC of the pre-service English teachers in a normal university from eight sub-dimensions. The results of the overall level of the ICC and the eight sub-dimensions are presented in Table 1. 
Table 1. Overview of the Pre-service Teachers' ICC

\begin{tabular}{llll}
\hline ICC Dimension & Average & $\mathrm{N}$ & $\mathrm{SD}$ \\
\hline Linguistic competence (D1) & 2.95 & 186 & 0.65 \\
Sociolinguistic competence (D2) & 3.28 & 186 & 0.61 \\
Discourse competence (D3) & 2.82 & 186 & 0.53 \\
Strategic competence (D4) & 3.81 & 186 & 0.64 \\
Knowledge (D5) & 2.78 & 186 & 0.3 \\
Attitudes (D6) & 3.87 & 186 & 0.60 \\
Awareness (D7) & 3.40 & 186 & 0.62 \\
Skills (D8) & 3.23 & 186 & 0.56 \\
Total & 3.20 & 186 & 0.69 \\
\hline
\end{tabular}

Note. $\mathrm{N}=$ No. of responses; $\mathrm{SD}=$ standard deviation

From Table 1, it can be seen that the preservice teachers' ICC gets a moderate overall average score of 3.20. Among the eight dimensions of ICC, the attitude (D6) received the highest score (3.87) while the knowledge (D5) receives the lowest (2.78), that means the pre-service English teachers' ICC levels in different dimensions were either high or moderate, without any dimension in low level.

Specifically, the eight sub-dimensions are presented as Attitudes $>$ Strategic competence $>$ Awareness $>$ Sociolinguistic competence $>$ Skills $>$ Linguistic competence $>$ Discourse competence $>$ Knowledge, in the order of their average scores.

Among the eight sub-dimensions, the average value of attitude (D6) is the highest, reaching 3.87, and then comes that of strategic competence (D4), which is 3.81. This shows that the pre-service English teachers have a highly positive attitude towards different cultures, a highly strong willingness to communicate interculturally or to overcome communication difficulties with verbal or non-verbal strategies. Awareness (D7) receives an average score of 3.40, which means the pre-service English teachers are moderately sensitive to different cultures and would take a critical attitude towards the cultural differences. Sociolinguistic competence (D2) and skills (D8) receive an average score of 3.28 and 3.23, respectively. This indicates that, in general, the pre-service English teachers have considerable socio-linguistic abilities and skills for coping with intercultural communication.

However, the average scores for the three sub-dimensions of linguistic competence (D1), discourse competence (D3) and knowledge (D5) are only, 2.95, 2.82 and 2.78, respectively. This shows that these three sub-dimensions greatly affected the overall ICC of the pre-service English teachers. Specifically, "linguistic competence" refers to "the ability to master language knowledge and the use of language skills", including phonetic, vocabulary and grammar knowledge, as well as the language skills of listening, speaking, reading, writing and translation (Hu \& Gao, 1997). Discourse competence refers to "the ability to organize utterances into cohesive, coherent and complete discourse", including initiate, terminate, or maintain communication (Wen, 1999). And "[intercultural] knowledge" refers to the "knowledge that learners should possess and use in the process of intercultural communication", including "social and cultural knowledge about their own and other's country" and "knowledge about communication processes at personal and social levels" (Byram, 1997).

From the results, it can be concluded that although the pre-service English teachers have a positive attitude towards and good willingness of intercultural communication, they lack sufficient knowledge and linguistic competence to assist their successful intercultural communication.

\subsection{The Level of Pre-Service English Teachers' ICC in Different Genders}

The participants consist of 15 male and 171 female pre-service English teachers. Table 2 presents the relationship between their ICC and their gender. 
Table 2. The Level of Participants' ICC in Different Genders

\begin{tabular}{llllllllll}
\hline & Total & D1 & D2 & D3 & D4 & D5 & D6 & D7 & D8 \\
\hline Male & 3.03 & 2.89 & 3.16 & 2.77 & 3.76 & 2.65 & 3.81 & 3.29 & 3.18 \\
Female & 3.21 & 2.96 & 3.29 & 2.83 & 3.83 & 2.79 & 3.87 & 3.41 & 3.23 \\
$\mathrm{t}$ & -6.31 & -4.85 & -6.43 & -4.76 & -2.15 & -2.76 & -5.84 & -6.32 & -6.61 \\
$\mathrm{p}$ & 0.027 & 0.030 & 0.024 & 0.044 & 0.083 & 0.079 & 0.030 & 0.016 & 0.009 \\
\hline
\end{tabular}

Note. D1=linguistic competence; D2=sociolinguistic competence; D3=discourse competence; D4=strategic competence (D4); D5=knowledge; D6=attitudes; D7=awareness; D8=skills.

From Table 2, it can be seen that, in terms of the overall ICC levels, female students scored higher than male students. The result of the test revealed a statistically significant difference between the ICC levels of the first-year students and the fourth-year students ( $\mathrm{p}=.027)$. As the eight dimensions of ICC are considered, a statistically significant difference was found between the female preservice English teachers and the males in terms of D1 or linguistic competence $(\mathrm{p}=0.030), \mathrm{D} 2$ or sociolinguistic competence $(\mathrm{p}=0.024), \mathrm{D} 3$ or discourse competence $(\mathrm{p}=0.044)$, D6 or attitudes $(\mathrm{p}=0.030), \mathrm{D} 7$ or awareness $(\mathrm{p}=0.016)$, D8 or skills $(\mathrm{p}=0.009)$. However, the independent sample t-test shows that there was no significant difference between female and male pre-service English teachers in terms of D4 or strategic competence $(\mathrm{p}=0.083)$ and D5 or knowledge dimension $(\mathrm{p}=0.079)$.

In summary, the results show that the female pre-service English teachers have higher ICC levels than male ones in overall and in six sub-dimensions, which means that the gender has a significant effect on the levels of ICC of the participants.

\subsection{The Level of Pre-Service English Teachers' ICC in Different Family Origins}

In this study, family origins refer to the participants' household types, which is divided into agricultural (rural) and non-agricultural (urban) according to their household registration information. The participants in this survey were from different family origins, with 127 students from rural families and 59 from urban families. The results of the pre-service English teachers' ICC levels in different family origins is presented in Table 3.

Table 3. The Level of Participants' ICC in Different Family Origins

\begin{tabular}{llllllllll}
\hline & Total & $\mathrm{D} 1$ & $\mathrm{D} 2$ & $\mathrm{D} 3$ & $\mathrm{D} 4$ & $\mathrm{D} 5$ & $\mathrm{D} 6$ & $\mathrm{D} 7$ & $\mathrm{D} 8$ \\
\hline Rural & 3.18 & 2.84 & 3.30 & 2.76 & 3.79 & 2.72 & 3.77 & 3.39 & 3.19 \\
Urban & 3.24 & 3.19 & 3.24 & 2.95 & 3.85 & 2.91 & 4.09 & 3.42 & 3.32 \\
$\mathrm{t}$ & -2.36 & -4.29 & 2.88 & -3.11 & -1.53 & -3.71 & -4.92 & -0.96 & -1.85 \\
$\mathrm{p}$ & 0.126 & 0.002 & 0.136 & 0.087 & 0.2330 & 0.027 & 0.006 & 0.343 & 0.269 \\
\hline
\end{tabular}

Note. $\mathrm{D} 1=$ linguistic competence; D2=sociolinguistic competence; D3=discourse competence; D4=strategic competence (D4); D5=knowledge; D6=attitudes; D7=awareness; D8=skills.

From Table 3, it is found that there is no significant difference between the overall ICC for the pre-service English teachers from urban areas and from rural areas $(\mathrm{p}=0.126)$, but the pre-service English teachers from urban areas were a little higher in ICC levels than those from rural areas. As for the eight sub-dimensions, the average scores for seven sub-dimensions of the urban pre-service English teachers are higher than those of rural ones, but the average score of the sociolinguistic competence (D2) of the pre-service English teachers from rural teachers are higher than that of those preservice English teachers from rural areas. Independent sample t-test showed a significant difference in three categories, that is, in D1 or linguistic competence $(\mathrm{p}=0.002), \mathrm{D} 5$ or knowledge $(\mathrm{p}=0.027)$ and $\mathrm{D} 6$ or attitudes $(\mathrm{p}=0.006)$. This indicates that although there is no significant difference between the overall ICC levels between the participants from urban families and those from rural families, but the participants from urban families are higher in ICC levels in terms of linguistic competence and language knowledge, and have a more positive attitude towards different cultures than those from rural families.

\section{Discussion}

The findings of this study revealed that the pre-service English teachers' overall ICC was just moderate (3.20), and the scores of two dimensions of strategic competence (D4) and attitudes (D6) were high, while the scores of the other six dimensions were moderate. This disconfirms Gao's (2014) study in which the overall ICC for English major undergraduates from 16 Chinese universities is satisfactory (3.73), but confirms Hua's (2019) study in which the overall ICC for English major undergraduates at an ethic university is not ideal (3.13). One 
reason for the inconsistent results was the participants were from different universities. In Gao's study, the participants were mostly from the key universities (985 or 211 universities, which are the top 100 universities among over 2000 universities in China). While in Hua's (2019) study and this study, the participants were from two ordinary local universities, so they did not have a good command of the language knowledge and skills, nor do they have any opportunities to meet or communicate with foreign teachers or visitors like those in the key universities in big cities. In addition, the pre-service English teachers in this study were admitted from junior middle schools, so they had received less English training than those who were admitted from the senior middle schools in other studies. Therefore, to ensure the ICC teaching goal of English teaching, the university should lay special emphasis on training and developing the pre-service English teachers' ICC, since teachers' ICC plays a vital role in the job of teaching. The pre-service English teachers should realize the importance of ICC in their teaching and try to improve it through different channels.

The study found that the pre-service English teachers were high in "attitudes" and "strategic competence" and "awareness" levels, while they were only acceptable in "knowledge", "linguistic competence" and "discourse competence" levels. The results are similar with both Gao's (2014) and Hua's (2019) studies, in which both "attitudes" and "awareness" scored much higher, and "linguistic competence" or "knowledge modular" scored the lowest. This suggests that Chinese students have an open attitude towards and strong willingness to participate the intercultural communication, and have many strategies for coping with the intercultural conversations, but their lack of sufficient vocabulary, grammar, and language skills impede them from effective and appropriate communication. This might be explained that there are not many communicating activities to practice the language acquired. Therefore, it is necessary to provide more opportunities to communicate interculturally for the pre-service English teachers.

This study also found that the female pre-service English teachers have higher ICC levels than the male ones. The results are in congruence with Gao's (2014) study, and it is explained by the difference between male's and female's brains. Females are better at intuitive thinking, memorizing, and expression; therefore, female English major students' ICC levels are higher than males. This could be one reason for the difference in ICC levels between male and female pre-service English teachers. Another reason might be that the number of males is much less than that of females in the Primary English Program, accounting about 10 percent. Then, in the classes, the males usually keep silent, passively taking part in classroom activities because they lack the support from male peers. Therefore, the results of the difference between males and females' ICC suggest that the university should adopt a more flexible class division policy.

The research also identified that the urban pre-service English teachers are a little higher than rural ones in ICC levels, especially in the sub-dimensions of linguistic competence (D1), knowledge (D5) and attitudes (D6). This might be explained by the difference in the teacher qualities, teaching facilities and methods because rural schools can easily attract good teachers and gain financial support than rural schools. In addition, the location of the schools can exert influence the students' knowledge and awareness, which in turn affect the students' ICC levels even after they enter the university.

\section{Conclusion}

In this study, a self-rating scale was used to investigate the pre-service English teachers' ICC levels and the correlations between their ICC levels and their gender as well as family origins at a Chinese public university. The results showed that the average overall ICC of the pre-service English teachers was 3.20, which is moderate. They have positive intercultural communication attitudes (average 3.87), but their intercultural knowledge needs improving (average 2.72).

Concerning the gender, the female pre-service English teachers' ICC overall levels were higher than the males'. Regarding the family origins, there was no significant difference in overall levels between the urban and the rural pre-service English teachers, but the urban ones scored a little higher than the rural ones in most ICC dimensions.

The results suggest that the university should lay more emphasis on the ICC development in the teaching, develop appropriate materials with intercultural knowledge, and provide more opportunities to communicate interculturally for the pre-service English teachers, especially for males and those from rural regions.

Nevertheless, this study has some limitations that should be noticed. Firstly, although the results of the self-assessment inventory presented a significant understanding of the pre-service English teachers' ICC levels, including other methods such as interviews or some objective testing methods would help to achieve a comprehensive evaluation. Secondly, the participants only involved the pre-service English teachers at one university, thus, having participants from more universities may present more evidence on the pre-service 
teachers' ICC levels. However, these limitations lead to several directions for future research. For example, future research could examine the pre-service teachers' perceptions of ICC and their practices of ICC teaching in the classroom. In addition, to improve the pre-service teachers' ICC levels, it is necessary to explore what factors, such as the institutional or the pre-service teachers' personal factors, may exert influence on their ICC development.

\section{References}

Alqefari, A. (2019). Exploring Teaching Intercultural Communicative Competence among Saudi University EFL Teachers (Unpublished doctoral dissertation). Tennessee: The University of Memphis.

Bennett, M. J. (1993). Toward ethnorelativism: A developmental model of intercultural sensitivity. In R. M. Paige (Ed.), Education for the Intercultural Experience (pp. 21-71). Yarmouth, ME: Intercultural.

Byram, M. (1986). Cultural studies in foreign-language teaching. Language Teaching, 19(4), 322-336. https://doi.org/10.1017/S0261444800011101

Byram, M. (1995). Acquiring intercultural competence. A review of learning theories. Intercultural Competence, 1, 53-70.

Byram, M. (1997). Teaching and Assessing Intercultural Communicative Competence. New York: Multilingual Matters.

Byram, M., \& Grundy, P. (2002). Context and culture in language teaching and learning. Language, Culture and Curriculum, 15(3), 193-195. https://doi.org/10.1080/07908310208666643

Chen, G. M. (1989). Relationships of dimensions of intercultural communication competence. Communication Quarterly, 37, 118-133. https://doi.org/10.1080/01463378909385533

Chen, G. M., \& Starosta, W. J. (1996). Intercultural Communication Competence: A Synthesis. Communication Yearbook, 19, 353-384. https://doi.org/10.1080/23808985.1996.11678935

Crozet, C. (2017). The Intercultural Foreign Language Teacher: Challenges and Choices. In M. Dasli \& A. R. Diaz (Eds.), The critical turn in language and intercultural communication pedagogy: Theory, research and practice (pp. 143-161). New York: Taylor \& Francis, Routledge.

Crozet, C., \& Liddicoat, A. J. (1999). The challenge of intercultural language teaching: Engaging with culture in the classroom. In J. Bianco, A. Liddicoat \& C. Crozet (Eds.), Striving for the third place: Intercultural competence through language education, (pp. 113-125). Melbourne VIC: Language Australia.

Deardorff, D. (2006). Identification and assessment of intercultural competence as a student outcome of internationalization. Journal of Studies in Intercultural Education, 3, 241-266. https://doi.org/10.1177/1028315306287002

Fantini, A. E., Arias-Galicia, F., \& Guay, D. (2001). Globalization and 21st century competencies: Challenges for North American higher education. Boulder, CO: Western Interstate Commission for Higher Education.

Gao, Y. C. (2014). Construction of theoretical framework of assessing intercultural communicative competence for Chinese college students. Foreign Language World, 4, 80-88.

Gao, Y. C. (2016). A survey on the intercultural communication competence of Chinese college students. Foreign Languages and Their Teaching, 2, 71-78.

Gao, Y. H. (2000). Understanding and transcending linguistic and cultural differences. Beijing: Foreign Language Teaching and Research Press.

Hammer, M. R., Bennett, M. J., \& Wiseman, R. L. (2003). Measuring intercultural sensitivity: The intercultural development inventory. International Journal of Intercultural Relations, 27, 421-443. https://doi.org/10.1016/S0147-1767(03)00032-4

$\mathrm{Hu}$, W. Z. (1999). Introduction to intercultural communication. Beijing: Foreign Language Teaching and Research Press.

Hua, Y. (2019). Survey on intercultural communication competence of English majors in ethnic colleges and universities: Taking Northwest Minzu University as example. China Educational Technology \& Equipment, 12, 74-78.

Jia, Y. X. (1997). Study on Intercultural Communication. Shanghai: Shanghai Foreign Language Education Press. 
Kelley, C., \& Meyers, J. (1995). The Cross-Cultural Adaptability Inventory: Self-Assessment. Minneapolis, MN: NCS Pearson.

Kim, M. S., \& Ebesu Hubbard, A. S. (2007). Intercultural communication in the global village: How to understand "the other". Journal of Intercultural Communication Research, 36(3), 223-235. https://doi.org/10.1080/17475750701737165

Liddicoat, A. J., \& Scarino, A. (2013). Intercultural language teaching and learning. Malden, MA: Wiley-Blackwell. https://doi.org/10.1002/9781118482070

Lin, D. J. (1996). Research in Intercultural Communication. Fuzhou: Fujian People's Press.

Ministry of Education. (2000). English teaching syllabus for English program in higher education. Beijing: Foreign Language Teaching and Research Press.

Ministry of Education. (2001). English curriculum standards. Beijing: Higher Education Press.

Ruben, B. D. (1976). Assessing communication competency for intercultural adaptation. Group \& Organization Studies, 1(3), 334-354. https://doi.org/10.1177/105960117600100308

Sercu, L. (2002). Implementing intercultural foreign language education. Belgian, Danish and British teachers' professional self-concepts and teaching practices compared. Evaluation \& Research in Education, 16(3), 150-165. https://doi.org/10.1080/09500790208667015

Sevimel-Sahin, A. (2020). A survey on the intercultural communicative competence of ELT undergraduate students. Eurasian Journal of Applied Linguistics, 6(2), 141-153. https://doi.org/10.32601/ejal.775793

Wen, Q. F. (1999). Oral English Testing and Teaching. Shanghai: Shanghai Foreign Language Education Press.

$\mathrm{Xu}, \mathrm{H}$. (2009). Cultivation of intercultural communicative competence in College English teaching. China Journal of Adult Education, 12, 131-132.

Zhang, W. D., \& Yang, L. (2012). Construction of Intercultural Communicative System: From the perspectives of Foreign Language Teaching and Empirical Research. Foreign Language World, 2, 8-16.

Zhong, H., Bai, Q. H., \& Fan, W. W. (2013). A trail study on construction of Intercultural communicative competence self-rating scale. Foreign Language World, 3, 47-56. 
Appendix: ICCSRS for the Pre-service English Teachers (adapted from Zhong et al., 2013)

\section{Section I: General Information}

1. Your gender: male female

2. Your Age:

3. Your Family origin: rural urban

\section{Section II: Self-rating Questions}

The following questions ask about your competence of communicating with people from different cultures. For each item below, please circle the number which best describes your opinions.

$1=$ strongly disagree; $2=$ disagree; $3=\mathrm{N} / \mathrm{U} ; 4=$ agree; $5=$ strongly disagree

\section{Linguistic competence (1-12 are reverse items)}

(1) The difficulty with my listening is that the other party speaks too fast and I can't react.

(2) The difficulty with my listening is that the other party has an accent, and I can't understand them clearly.

(3) The difficulty with my speaking is that I can't express myself changes in phonetic intonation.

(4) The difficulty with my speaking is stuttering and poor coherence.

(5) The difficulty with my speaking is that I only know the meaning of words, but there are obstacles in the organizing the words into sentences.

(6) The difficulty with my speaking is that I will make a lot of grammatical errors.

(7) The difficulty with my speaking is that I can only roughly describe or express my ideas, not in details.

(8) The difficulty in speaking is that I will not use euphemisms to express some taboos.

(9) The difficulty with my speaking is that I cannot explain things unique to China, such as local customs, to the people from other cultures.

(10) The difficulty with my reading is that I cannot understand a difficult article even with a dictionary.

(11) The difficulty with my writing is that there are many errors in my written articles.

(12) The difficulty with my translation is that I mainly think in Chinese, therefore my translation is relatively poor.

\section{Sociolinguistic competence}

(13) I can adjust my ways of speaking according to different communication situations.

(14) I can adjust my ways of speaking based on the age of the other party.

(15) I can adjust my ways of speaking according to the gender of the other party.

(16) I can adjust my ways of speaking based on the identity and status of the other party.

(17) I can adjust my ways of speaking based on how close I am to the other party.

\section{Discourse competence}

(18) I can choose the right topic when communicating with people from different cultures.

(19) I was able to continue the conversation smoothly when communicating with people from different cultures.

(20) When communicating with people from different cultures, I was able to start and end conversations appropriately and naturally.

\section{Strategic competence $(21,22,25$ are reverse items)}

(21) I will keep silent when I encounter something I cannot express in English.

(22) I will avoid the topic in which I am not able to express my ideas.

(23) When I encounter words that I cannot remind, I will choose other words with similar meanings instead.

(24) When I encounter something that cannot be expressed in a word, I will use a long sentence to explain it.

(25) I even speak Chinese unconsciously sometimes when I encounter a meaning that I cannot express in English.

(26) I will use conversation fillers such as "er" or "well" to win time for thinking. 
(27) When I encounter communication difficulties, I will ask the other party to repeat or reorganize the language. (28) I can repeat the other person's words in a questioning tone, implying that I have difficulty in understanding them.

\section{Knowledge (29-34 are reverse items)}

(29) When communicating with people from different cultures, I don't know the lifestyle of the other culture.

(30) When communicating with people from different cultures, I don't know the historical events and historical figures of the other culture.

(31) When communicating with people from different cultures, I don't know the literature and important writers of the other culture.

(32) When communicating with people from different cultures, I don't know the politics of the other's culture

(33) When communicating with people from different cultures, I don't understand the taboos of the other culture.

(34) I don't understand non-verbal communication including gestures and posture.

(35) When communicating with people from different cultures, I understand the customs and habits of the other culture.

(36) When communicating with people from different cultures, I understand the current important events and hot events in the other culture.

(37) When communicating with people from different cultures, I understand the appropriate body distance in each other's culture.

(38) When communicating with people from different cultures, I understand the time concept of the other culture.

(39) When I talk to people from different cultures, I understand the geography of their culture.

\section{Attitudes}

(40) I am very interested in the lifestyle and values of different countries, and I am willing to communicate with people from different cultures.

(41) I like to actively communicate with people from different cultures.

(42) If people from different cultures take the initiative to communicate with me, I can respond positively.

(43) When communicating with people from different cultures, if the other person's point of view is different from mine, I can respect the other person's point of view.

\section{Awareness ( 45 is reverse item)}

(44) When communicating with people from different cultures, I am good at observing cultural differences between each other.

(45) When communicating with people from different cultures, I don't understand certain values of the other culture, and I won't accept them.

\section{Skills (47-49 are reverse items)}

(46) When interacting with people from different cultures, I can get along well with each other.

(47) When communicating with people from different cultures, I find it difficult to cope with the conflicts caused by cultural differences.

(48) When communicating with people from different cultures, I find it difficult to flexibly adjust my communication behavior according to the cultural background of both parties.

(49) When communicating with people from different cultures, I do not actively explain the misunderstandings that occur.

(50) When communicating with people from different cultures, I can deal with various social situations and relationships.

\section{Copyrights}

Copyright for this article is retained by the author(s), with first publication rights granted to the journal.

This is an open-access article distributed under the terms and conditions of the Creative Commons Attribution license (http://creativecommons.org/licenses/by/4.0/). 